\title{
Świadomość stanów emocjonalnych a osiągnięcia w nauce szkolnej uczniów słabowidzących w okresie wczesnej adolescencji
}

\begin{abstract}
Izabella Kucharczyk, Świadomość stanów emocjonalnych a osiagnięcia w nauce szkolnej uczniów słabowidzacych w okresie wczesnej adolescencji [Emotional awareness and educational achievements of students with visual impairments in early adolescence]. Interdyscyplinarne Konteksty Pedagogiki Specjalnej, nr 18, Poznań 2017. Pp. 73-91. Adam Mickiewicz University Press. ISSN 2300-391X

The purpose of this article is to present the results of research beteween emotional awareness and educational achievements of students with visual impairments in early adolescence. The study included 60 students studying in secondary schools in the Mazovian region. The study used Emotion Awareness Questionnaire - Revised EAS-30-R. Rieffe, P. Oosterveld, A.C. Miers, M.M. Terwogt in the Polish adaptation of I. Kucharczyk and A. Dłużniewska and school grades.
\end{abstract}

KEY WORDS: self-awareness emotions, emotions, students with visual impairments

\section{Wprowadzenie}

Emocje odgrywają ważną rolę w rozwoju każdego człowieka. Wpływają na relacje społeczne, sposób zachowania, poczucie własnej skuteczności, samoocenę, pozwalają na odpowiednie reakcje 
w sytuacjach trudnych. Okres adolescencji to czas, w którym pojawić się może nie tylko kryzys tożsamości, ale również labilność emocjonalna wynikająca ze zmian hormonalnych. To także etap przemian fizjologicznych prowadzących do transformacji obrazu własnej osoby ${ }^{1}$. Emocje w okresie adolescencyjnym uaktywniają się w zależności od działających w danym momencie bodźców, a reakcje zależą od procesów pobudzania i hamowania układu nerwowego².

W okresie dorastania młoda osoba staje się coraz bardziej świadoma doświadczanych i przeżywanych emocji. Jest to związane z procesem kształtowania i doskonalenia umiejętności rozpoznawania własnych emocji oraz nabywanych kompetencji społecznych. Dzieje się tak dzięki roli, jaką zaczyna odgrywać inteligencja emocjonalna.

\section{Pojęcie inteligencji emocjonalnej}

Pojęcie inteligencji emocjonalnej $w$ literaturze naukowej zostało rozpropagowane $\mathrm{w}$ latach $80 . \mathrm{XX} \mathrm{w}$. Za jego prekursora uważa się Howarda Gardnera, który wskazywał na istnienie inteligencji interpersonalnej (zdolność rozumienia ludzi) i inteligencji intrapersonalnej umożliwiającej introspekcję własnych emocji, identyfikowanie ich i uwzględnianie $\mathrm{w}$ podejmowaniu różnych decyzji, co ma przełożenie na zachowanie ${ }^{3}$. Do nauk społecznych i humanistycznych pojęcie to zostało wprowadzone przez Petera Saloveya i Johna D.

${ }^{1}$ I. Obuchowska, Adolescencja, [w:] Psychologia rozwoju człowieka. Charakterystyka okresów życia, red. B. Harwas-Napierała, J. Trempała, PWN, Warszawa, 2000, t. 2, s. 152-155; M. Radochoński, Psychopatologia życia emocjonalnego dzieci i młodzieży. Wybrane zagadnienia, Wydawnictwo Uniwersytetu Rzeszowskiego, Rzeszów 2009.

2 R.A. Thompson, Emotion regulation: a theme in search of definition. "Monographs of the Society for Reaserch in Child Development" 1994, nr 2-3, s. 25-52.

${ }^{3}$ M. Ledzińska, Elementy poznawcze i metapoznawcze w inteligencji - od inteligencji poznawczej do emocjonalnej. „Psychologia Wychowawcza” 1999, 42, s. 1-10; H. Gardner, Inteligencje wielorakie. Teoria w praktyce, Media Rodzina, Poznań 2002. 
Mayera $^{4}$, a rozpropagowane przez Daniela Golemana ${ }^{5}$. Zdaniem tego ostatniego rozwój ucznia zależy nie tylko od możliwości poznawczych, ale głównie od poziomu inteligencji emocjonalnej rozumianej jako zbiór uzdolnień i kompetencji zwiększających osobistą i interpersonalną aktywność ujawniającą się $\mathrm{w}$ relacjach społecznych z innymi.

Mimo kilkudziesięciu lat badań nad tym zagadnieniem nie udało się badaczom wypracować jednego stanowiska charakteryzującego inteligencję emocjonalną. Niektórzy traktują ją jako zdolność (zbiór zdolności), na którą składają się cztery grupy umiejętności: zdolności percepcji i wyrażania emocji; zdolności emocjonalne wspierające myślenie; zdolności rozumienia i wykorzystywania emocji w różnych sytuacjach; zdolności świadomej regulacji emocjonalnej, czyli procesy pobudzania i hamowania emocji w sytuacjach społecznych6.

Inni rozpatrują inteligencję emocjonalną jako wiedzę, czyli zbiór doświadczeń o charakterze emocjonalnym, włączonych do struktur poznawczych7. Mówiąc o inteligencji emocjonalnej jako wiedzy, należy pamiętać, że na tę wiedzę składają się informacje na temat przyczyn pojawiania się emocji, słowa określające stany emocjonalne, dane o ekspresji emocjonalnej w sytuacjach społecznych, wpływ emocji na podejmowane działanie oraz samoświadomość występujących emocji i sposoby reagowania ${ }^{8}$.

4 P. Salovey, J.D. Mayer, Emotional intelligence, “Imagination, Cognition, and Personality" 1990, 9, s. 85-211.

${ }^{5}$ D. Goleman, Inteligencja emocjonalna. Sukces w życiu zależy nie tylko od intelektu lecz od umiejętności kierowania emocjami, Media Rodzina, Poznań 2012; S. Rietti, Emotional Intelligence as Educational Goal: A Case for Caution, "Journal of Philosophy of Education", 2008, 42(3-4), s. 631-643; M. Feldmann, P. Jeffery, Co-curricular Assessment Scale Development, “The Journal of General Education" 2011, 60, 1, s. 16-42.

${ }^{6}$ P. Salovey, J.D. Mayer, Emotional intelligence. "Imagination, Cognition, and Personality" 1990, 9, s. 185-211.

${ }^{7}$ C.E. Izard, Emotional intelligence or adaptive emotions?, "Emotion" 2001, 1, s. 249-257.

${ }^{8}$ A. Matczak, K.A. Knopp, Znaczenie inteligencji emocjonalnej w funkcjonowaniu człowieka, Wydawnictwo Stowarzyszenie Filomatów, Liberi Libri 2013. 
Trzecia grupa badaczy, m.in. Konstanty V. Petrides i Adrian Furnham inteligencję emocjonalną traktują jako cechę (zbiór różnych cech). Oznacza to, że każda osoba dokonuje subiektywnej oceny swoich zdolności emocjonalnych $\mathrm{w}$ zakresie rozpoznawania, przetwarzania i wykorzystywania ich w różnych sytuacjach 9 .

Ostatnia grupa naukowców m.in. Reuven Bar-On ${ }^{10}$ uważa inteligencję emocjonalną za kompetencję lub ich zbiór. Jego zdaniem inteligencja emocjonalna to grupa zdolności pozapoznawczych, które pozwalają człowiekowi na emocjonalne radzenie sobie w różnych zadaniach społecznych, mniej lub bardziej trudnych. Autor zwrócił też uwagę na pięć komponentów inteligencji emocjonalnej, które są niezbędne do osiągnięcia powodzenia społecznego. Należą do nich: składnik interpersonalny, intrapersonalny, przystosowawczy, składnik pozwalający na radzenie sobie ze stresem i z nastrojem. Inteligencję emocjonalną jako kompetencję traktuje również D. Goleman11, który wyróżnił pięć jej składowych: samoświadomość (czyli wiedzę na temat przeżywanych emocji), samoregulację (czyli zdolność do kontrolowania emocji), motywację do działania (z użyciem emocji), empatię (czyli umiejętność wczuwania się w stany emocjonalne innych osób), umiejętności społeczne (zdolność do nawiązywania kontaktów z innymi ludźmi i wywoływanie odpowiednich reakcji ze strony ludzi).

Carolyn Saarni uważa, że zamiast pojęcia inteligencji emocjonalnej należałoby posługiwać się terminem kompetencji emocjonalnej. W swojej koncepcji wyróżnia ona osiem różnych składowych, przy czym jedne odkreślane są mianem umiejętności, a inne zdolno-

${ }^{9}$ A. Wytykowska, K.V. Petrides, Inteligencja emocjonalna jako dyspozycja. Polska adaptacja skali do badania inteligencji emocjonalnej jako cechy TEIque Petridesa i Furnhama, „Psychologia, Edukacja i Społeczeństwo” 2007, 4, s. 97-110.

${ }^{10}$ R. Bar-On, Emotional Quotient Inventory. A measure of emotional intelligence. User's manual, Multi-Health Systems Inc., Toronto 1997, s. 3.

11 D. Goleman, Inteligencja emocjonalna w praktyce, Media Rodzina, Poznań 1999; A. Jaworowska, A. Matczak, Kwestionariusz Inteligencji Emocjonalnej INTE S. Schutte, J. M. Malouffa, L. E. Hall, D. J. Haggerty'ego, J. T. Cooper, C. J. Goldena, L. Dornheim. Podręcznik, Pracownia Testów Psychologicznych PTP, Warszawa 2008. 
ści. Autorka jest zdania, że kompetencje te mają za zadanie pomóc jednostce $\mathrm{w}$ różnych sytuacjach społecznych odpowiednio reagować pod wpływem emocji, ale też dają możliwość wykorzystywania ich $w$ interakcjach $z$ innymi ludźmi. Im wyższy jest poziom jednej zdolności, tym poziom kolejnej również będzie wzrastać12.

Inteligencja emocjonalna nie jest czymś wrodzonym, a kształtuje się wraz z wiekiem. Z analizy literatury przedmiotu wynika, że badacze nie są zgodni co do czynników determinujących inteligencję emocjonalną. Jedna część uważa, że zależy ona od uwarunkowań biologicznych, a druga grupa naukowców twierdzi, że na jej rozwój wpływają czynniki społeczne ${ }^{13}$.

Podsumowując, w niniejszym artykule przyjmuje się, że inteligencja emocjonalna to zespół zdolności radzenia sobie w różnych sytuacjach społecznych w wyniku nabytych umiejętności dotyczących emocji oraz wiedzy na ich temat ${ }^{14}$.

\section{Inteligencja emocjonalna a niepełnosprawność wzroku}

Okres dorastania to czas, kiedy uczeń uczy się radzić sobie z trudnościami wynikającymi m.in. z labilności emocjonalnej. Na tym etapie młodzież musi zmierzyć się ze zmianami w postrzeganiu siebie i innych, szuka aprobaty społecznej w grupie rówieśników, porównuje siebie do innych. Dla ucznia z niepełnosprawnością wzroku jest to tak samo trudny okres jak dla widzącego. Przeżywa on takie same rozterki i doświadcza dysonansów społecznych tak samo jak jego widzący rówieśnicy. Badań na temat

12 C. Saarni, Kompetencja emocjonalna i samoregulacja w dzieciństwie, [w:] Rozwój emocjonalny a inteligencja emocjonalna, red. P. Salovey, D.J. Slyter, Dom Wydawniczy Rebis, Poznań 1999, s. 75-125.

${ }^{13}$ D. Goleman, op. cit.; A. Matczak, Zarys psychologii rozwoju. Podręcznik dla nauczycieli, Wydawnictwo Akademickie „Żak”, Warszawa, 2003; J.D. Mayer, P. Salovey, Czym jest inteligencja emocjonalna?, [w:] Rozwój emocjonalny a inteligencja emocjonalna, red. P. Salovey, D. Sluyter, Dom Wydawniczy Rebis, Poznań 1999, s. 23-74.

14 A. Jaworowska, A. Matczak, op. cit. 
inteligencji emocjonalnej słabowidzących lub niewidomych adolescentów w literaturze światowej i polskiej jest stosunkowo niewiele.

Problem rozwoju inteligencji emocjonalnej u uczniów z niepełnosprawnością wzroku podjęli Muhammmad Arshad i Muhammad Aslad Lodhi ${ }^{15}$. Przebadali 30 uczniów niewidomych i 30 uczniów słabowidzących w wieku od 8 do 18 lat, z wykorzystywaniem Kwestionariusza do badania Inteligencji Emocjonalnej Baron EQ-1-YU, składającego się z 60 itemów, podzielonych na 7 podskal (zdolności intrapersonalne, interpersonalne, zdolności do adaptacji, radzenie sobie ze stresem, ogólny nastrój, pozytywne wrażania i brak konsekwencji w zachowaniu). Zdaniem autorów brak wzroku potęguje trudności $w$ radzeniu sobie $z$ wyzwaniami dnia codziennego. Uczniowie $\mathrm{z}$ niepełnosprawnością wzroku w wieku adolescencyjnym ze względu na ograniczone zasoby dotyczące m.in. rozumienia własnych emocji są bardziej drażliwi, niepewni, cechują się częściej niż rówieśnicy obniżoną samooceną i złym samopoczuciem. Arshad i Muhammad Aslad Lodhi ustalili również, że grupa ta charakteryzuje się obniżoną ilością kontaktów społecznych.

Badania prowadzone przez Kumar i Singh ${ }^{16}$ na grupie 150 uczniów z niepełnosprawnością wzroku i równolicznej grupie widzących rówieśników studiujących w szkołach wyższych w Indiach wykazały, że uczniowie z uszkodzonym wzrokiem charakteryzują się niższym poziomem inteligencji emocjonalnej.

Z kolei badania Rekhy Rani ${ }^{17}$ dotyczące inteligencji emocjonalnej uczniów słabowidzących i niewidomych przeprowadzone w szkołach specjalnych i integracyjnych w Delphi pokazały, że uczniowie edukowani w szkołach integracyjnych mają wyższy poziom

${ }_{15}$ M. Arshad, M. Lodhi, Congenital Blind and Sight; Emiotional Inteligence Sighted. "The Proffesional Medical Journal" 2015, 22(10), s. 1336-1344.

16 S. Kumar, J. Singh, Emotional intelligence and adjustment among visually impairment and sighted school students, "Asian Journal of Multi-Dimensional Research" 2013, 2(8), s. 1-8.

17 R. Rani, Emotional intelligence and academic achievement of visually disabled students in integrated and segregated schools. "Disabilities and Impairments" 2011, 25 (1\&2), s. 44-50. 
inteligencji emocjonalnej. Wykazano istnienie korelacji między zarówno typem szkoły, jak i osiągnięciami akademickimi, a poziomem inteligencji emocjonalnej. Powyższe wnioski potwierdzają również badania S. Parween ${ }^{18}$.

Zdaniem Lee A. Beaty brak wzroku może przyczyniać się do niechęci do podejmowania w przyszłości pracy, niskiej akceptacji społecznej, niskich wyników akademickich i niskiego poziomu samooceny. Trudności te często u nastolatków mogą doprowadzać do występowania różnych problemów psychicznych, głównie o charakterze emocjonalnym ${ }^{19}$.

\section{Metodologia badań własnych}

Aby uczeń mógł się rozwijać, należy zapewnić mu odpowiednie warunki. Środowisko wychowawcze i społeczne odgrywa jedną z najważniejszych ról. Pozwala poznawać siebie. Rozwój sfery emocjonalnej warunkuje rozwój inteligencji emocjonalnej. Brak danych sensorycznych nie tyle uniemożliwia, co opóźnia nabywanie umiejętności związanych z analizą pojawiających się i odczuwanych emocji. Wymaga to od uczniów większej pracy nad sobą, ale też i nauczenia się odpowiednich sposobów reagowania.

Celem zaprezentowanych badań było uzyskanie odpowiedzi na pytania: Czy i jakie istnieją różnice w zakresie osiągnięć szkolnych uczniów z niepełnosprawnością wzroku i uczniów widzących w okresie adolescencji? Czy i jakie istnieją zależności pomiędzy samoświadomością stanów emocjonalnych pojawiających się u uczniów z niepełnosprawnością wzroku znajdujących się w okresie adolescencji a ich osiągnięciami w nauce szkolnej?

18 S. Parween, Variables Influencing Emotional Intelligence of Visually Impaired Students in Higher Education. "Disability, CBR and Inclusive Development DCID" 2015, vol. 26(1), s. 97-108.

${ }^{19}$ L.A. Beaty, Adolescent self-perception as a function of vision loss, "Adolescence" 1992, 27, s. 707-714. 
W badaniach własnych zastosowano metodę sondażu diagnostycznego, natomiast jako narzędzie badawcze wykorzystano kwestionariusz Emotion Awareness Questionnaire - Revised EAQ-30-R. Carolien Rieffe, Paula Oostervelda, Anne C. Miersa, Marka M. Terwogta oraz Vereny Ly ${ }^{20}$ w polskiej wersji językowej Izabelli Kucharczyk i Agnieszki Dłużniewskiej21. Kwestionariusz ten składa się z 30 twierdzeń. Przeznaczony jest do badania świadomości własnych stanów emocjonalnych młodzieży od 12. do 17. roku życia. Obszary badane w kwestionariuszu obejmują następujące kategorie: Identyfikowanie Emocji (7 itemów), Werbalizowanie Emocji (3 itemy), Ujawnianie Emocji (5 itemów), Świadomość Reakcji Fizjologicznych Organizmu (5 itemów), Empatia (5 itemów), Analiza Własnych Emocji (5 itemów). W kwestionariuszu autorzy zastosowali 3-stopniową skalę Likerta. W celu określenia osiągnięć szkolnych wzięto pod uwagę średnie, jakie uczniowie otrzymali z poszczególnych przedmiotów.

W poniższym artykule wzięto pod uwagę tylko niektóre składowe inteligencji emocjonalnej, zgodnie z rozumieniem Golemana. Wynikało to z budowy i założeń kwestionariusza EAQ-30-R C. Rieffe'a, P. Oostervelda, A.C. Miersa, M.M. Terwogta i V. Ly zastosowanego w poniższych badaniach. Goleman wyróżnił pięć elementów inteligencji emocjonalnej (takich jak: samoświadomość emocji, samoregulacja emocji, motywacja do działania, empatia, umiejętności społeczne). Natomiast w kwestionariuszu EAQ-30-R autorzy

${ }^{20}$ C. Rieffe, P. Oosterveld, A.C. Miers, M.M. Terwogt, V. Ly, Emotion Awareness and Internalizing Symptoms in Children and Adolescents; The Emotion Awareness Questionnaire Revised, „Personality and Individual Differences” 2008, nr 45, s. 756-761.

${ }^{21}$ Rzetelność podskal kwestionariusza EAQ sprawdzano określając ich zgodność wewnętrzną i stabilność bezwzględną. Współczynniki zgodności i stabilności wyniosły od 0,74 do 0,77 . Kwestionariusz został przetłumaczony na język polski i zaadaptowany w ramach projektu badawczego pt. „Samoświadomość emocji i kompetencje społeczne a osiągnięcia edukacyjne młodzieży szkół gimnazjalnych z i bez specyficznych trudności w uczeniu się" finansowanego przez Akademię Pedagogiki Specjalnej im. M. Grzegorzewskiej w Warszawie (BSTP WNP 16/17 I). W przeprowadzonych badaniach współczynnik zgodności wewnętrznej a Cronbacha wyniósł powyżej 0,81 . 
wyróżnili podskale Identyfikowanie Emocji, Werbalizowanie Emocji i Analiza Własnych Emocji jako odpowiednik samoświadomości w koncepcji Golemana; Ujawnianie Emocji jako odpowiedni samoregulacji. Zarówno D. Goleman jak i C. Rieff, P. Oosterveld, A.C. Miers, M.M. Terwogt i V. Ly wyróżnili Empatię. Dodatkowo zamieszczono podskalę jak Świadomość Reakcji Fizjologicznych Organizmu, natomiast nie uwzględniono takiej składowej jak umiejętności społeczne i motywacja do działania wskazane przez Golemana.

\section{Organizacja i teren badań}

Przeprowadzone badania objęły 30 uczniów z niepełnosprawnością wzroku (osoby słabowidzące $\mathrm{z}$ ostrością wzroku w przedziale 0,03 do 0,01 bez dodatkowych sprzężeń) oraz 30 uczniów widzących.

27 uczniów słabowidzących to uczniowie Specjalnego Ośrodka Szkolno-Wychowawczego im. Zofii Galewskiej w Warszawie, 3 uczniów uczęszczało do ogólnodostępnej szkoły integracyjnej w Warszawie. Uczniowie widzący byli uczniami ogólnodostępnego gimnazjum także w Warszawie. Dobór osób do grupy pierwszej (uczniów słabowidzących) był celowy (grupę tę dobrano ze względu na niepełnosprawność wzroku), a do grupy widzących - losowy.

Grupy dobrane zostały równolicznie $-\mathrm{z}$ klasy I gimnazjum po 7 uczniów, z klasy II - po 11 uczniów i z klasy III - po 12 uczniów. Badania zostały przeprowadzone w lutym-marcu $2017 \mathrm{r}$.

\section{Analiza i interpretacja wyników}

W tabeli 1. przedstawiono dane dotyczące statystyk opisowych poszczególnych podskal kwestionariusza EAQ-30-R przeznaczonego do badania świadomości emocji. Szczegółowa analiza danych liczbowych uzyskanych w procesie badawczym pozwala zauważyć, że uczniowie słabowidzący osiągnęli w zakresie Analizy Wtasnych Emocji (średni otrzymany wynik to 2,500; $\mathrm{SD}=0,447$; minimalny 1,8 
a maksymalny - 3) najwyższy rezultat ze wszystkich 6 podskal. Z kolei najniższy wynik został osiągnięty w zakresie Świadomość Reakcji Fizjologicznych Organizmu ( $\mathrm{M}=1,646$; $\mathrm{SD}=0,483$; wynik minimalny - 1; wynik maksymalny 2,6). W grupie uczniów widzących wyniki te są niewiele wyższe. Najwyższy został osiągnięty w podskali Ujawnianie Emocji $(\mathrm{M}=2,353$; $\mathrm{SD}=0,405$; wynik minimalny 1,6; wynik maksymalny 3), a najniższy w podskali Identyfikowanie Emocji $(\mathrm{M}=2,15 ; \mathrm{SD}=0,579$; wynik minimalny - 1,14; wynik maksymalny 3$)$.

Tabela 1. Statystyki opisowe uzykane przez badanych uczniów w kwestionariuszu Emotion Awareness Questionnaire - Revised EAS-30-R. C. Rieffe, P. Oostervelda, A.C. Miersa, M.M. Terwogta, V. Ly

\begin{tabular}{|c|c|c|c|c|c|c|c|c|c|c|}
\hline Podskala & $\begin{array}{c}\text { Grupa } \\
\text { uczniów }\end{array}$ & $\mathrm{N}$ & M & SD & $\begin{array}{l}\mathrm{M}: \mathrm{M} \\
\max \\
\mathrm{w} \%\end{array}$ & w. min. & w. $\max$ & $\begin{array}{c}\mathrm{X}_{\mathrm{typ}} \\
(\mathrm{M} \pm \mathrm{SD})\end{array}$ & k & g \\
\hline \multirow{2}{*}{$\begin{array}{l}\text { Identyfiko- } \\
\text { wanie Emocji }\end{array}$} & US & 30 & 2,100 & 0,547 & 70,00 & 1,20 & 3 & $1,553-2,647$ & $-1,02$ & ,081 \\
\hline & UW & 30 & 2,15 & 0,579 & 71,66 & 1,14 & 3 & $1,195-3,385$ & 819 & 1,628 \\
\hline \multirow{2}{*}{$\begin{array}{l}\text { Werbalizo- } \\
\text { wanie Emocji }\end{array}$} & US & 30 & 1,800 & 0,610 & 60,00 & 1 & 3 & $1,190-2,41$ &,- 380 & ,514 \\
\hline & UW & 30 & 2,222 & 0,555 & 74,00 & 1 & 3 & $1,667-2,777$ &,- 610 &,- 145 \\
\hline \multirow{2}{*}{$\begin{array}{l}\text { Ujawnianie } \\
\text { Emocji }\end{array}$} & US & 30 & 1,995 & 0,460 & 65,00 & 1 & 2,86 & $1,535-2,460$ &,- 322 & ,112 \\
\hline & UW & 30 & 2,353 & 0,405 & 78,43 & 1,6 & 3 & $1,948-2,758$ &,- 813 & ,181 \\
\hline \multirow{2}{*}{$\begin{array}{l}\text { Świadomość } \\
\text { Reakcji Fizjo- } \\
\text { logicznych } \\
\text { Organizmu }\end{array}$} & US & 30 & 1,646 & 0,483 & 54,86 & 1 & 2,6 & $1,163-2,129$ & $-1,07$ & ,427 \\
\hline & UW & 30 & 2,193 & 0,652 & 73,10 & 1 & 3 & $1,541-2,845$ & $-1,44$ &,- 140 \\
\hline \multirow{2}{*}{ Empatia } & US & 30 & 1,793 & 0,513 & 59,76 & 1 & 2,6 & $1,28-2,306$ & $-1,215$ & 833 \\
\hline & UW & 30 & 2,273 & 0,447 & 75,76 & 1,4 & 3 & $1,826-2,72$ &,- 526 & 179 \\
\hline \multirow{2}{*}{$\begin{array}{l}\text { Analiza } \\
\text { własnych } \\
\text { emocji }\end{array}$} & US & 30 & 2,500 & 0,447 & 83,33 & 1,8 & 3 & $2,053-2,947$ & $-1,415$ & ,833 \\
\hline & UW & 30 & 2,233 & 0,100 & 74,43 & 1,2 & 3 & $2,133-2,333$ & $-1,293$ &,- 131 \\
\hline
\end{tabular}

Objaśnienia do tabeli: US - uczniowie słabowidzący; UW - uczniowie widzący; M - średnia arytmetyczna; SD - odchylenie standardowe; w.min. - najmniejszy wynik uzyskany $\mathrm{w}$ danej kategorii; w.max. - największy wynik uzyskany w danej kategorii; Xtyp - granice obszaru typowego; k - kurtoza; g - skośność (współczynnik asymetrii rozkładu) 
Kolejnym punktem analiz jest określenie istotności różnic statystycznych w średniej uzyskanej dla ocen z poszczególnych przedmiotów dla uczniów słabowidzących oraz widzących (tabela 2). Wzięto pod uwagę średnie ocen, jakie uczniowie otrzymali na koniec semestru zimowego w roku szkolnym 2016/2017.

Tabela 2. Różnice w średniej uzyskanej dla ocen z przedmiotów dla badanej grupy uczniów słabowidzących $(\mathrm{N}=30)$ i widzących $(\mathrm{N}=30)$ w okresie adolescencji

\begin{tabular}{|l|c|c|c|c|c|c|c|}
\hline \multirow{2}{*}{ Zmienna } & \multicolumn{2}{|c|}{$\begin{array}{c}\text { Uczniowie słabowidzący } \\
(\mathrm{N}=30)\end{array}$} & \multicolumn{2}{|c|}{$\begin{array}{c}\text { Uczniowie widzący } \\
(\mathrm{N}=30)\end{array}$} & \multirow{2}{*}{$\mathrm{t}$} & $\mathrm{d}$ & $\mathrm{p}$ \\
\cline { 2 - 6 } & $\mathrm{M}$ & $\mathrm{SD}$ & $\mathrm{M}$ & $\mathrm{SD}$ & & & \\
\hline Zachowanie & 3,766 & 1,040 & 4,793 & 1,322 & $-3,342$ & 58 & $0,001^{*}$ \\
\hline Język polski & 2,700 & 1,055 & 3,016 & 1,163 & $-1,104$ & 58 & 0,273 \\
\hline Język obcy & 2,766 & 1,194 & 3,00 & 1,159 & $-0,768$ & 58 & 0,466 \\
\hline Historia & 2,666 & 0,088 & 3,233 & 1,330 & $-1,943$ & 58 & $0,057^{*}$ \\
\hline Geografia & 2,866 & 0,899 & 3,536 & 0,905 & $-2,875$ & 58 & $0,006^{*}$ \\
\hline Biologia & 3,100 & 0,994 & 3,250 & 0,953 & $-0,596$ & 58 & 0,553 \\
\hline Chemia & 2,356 & 0,615 & 3,133 & 0,964 & $-3,718$ & 58 & $0,001^{*}$ \\
\hline Fizyka & 2,566 & 0,552 & 3,183 & 0,951 & $-3,070$ & 58 & $0,003^{*}$ \\
\hline Matematyka & 2,500 & 1,042 & 3,050 & 1,020 & $-2,066$ & 58 & $0,043^{*}$ \\
\hline Informatyka & 3,646 & 0,802 & 5,233 & 0,597 & $-8,681$ & 58 & $0,000^{*}$ \\
\hline Zajęcia artystyczne & 4,420 & 0,829 & 3,193 & 1,013 & 5,130 & 58 & $0,000^{*}$ \\
\hline Zajęcia techniczne & 4,613 & 0,808 & 4,866 & 0,776 & $-1,238$ & 58 & $0,022^{*}$ \\
\hline
\end{tabular}

Objaśnienia to tabeli: M - średnia arytmetyczna; SD - odchylenie standardowe; $\mathrm{t}$ - wartość testu ",t" Studenta; df - stopnie swobody; p - poziom istotności; * istotność statystyczna na poziomie 0,01

Uczniowie słabowidzący najwyższe średnie uzyskali z przedmiotu: zajęcia techniczne $(\mathrm{M}=4,613)$. Jest on niższy od wyniku uczniów widzących o 0,253. Na drugim miejscu plasują się wyniki $\mathrm{z}$ zajęć artystycznych $(\mathrm{M}=4,420)$ i jest to jednocześnie jedyny przedmiot, w którym uczniowie z niepełnosprawnością wzroku osiągają wyższe rezultaty od widzących rówieśników o 1,227. 
Najniższą średnią otrzymali uczniowie słabowidzący z chemii $(\mathrm{M}=2,356)$ i jest to wynik niższy od widzących 0,$777 ; \mathrm{z}$ matematyki $(\mathrm{M}=2,500)$ oraz z fizyki $(\mathrm{M}=2,566)$. Przedmioty te są przedmiotami typowo ścisłymi wymagającymi od uczniów koncentracji, ale też obserwacji szczegółów, zmiany działań, zmiany znaków przy obliczeniach, dużej skrupulatności. Uczeń słabowidzący nie zawsze ma możliwość dokładnego prześledzenia obliczeń matematycznych, gdyż używając lup czy powiększalników, może nie zapamiętywać poszczególnych znaków, zamiany symboli, łatwiej mu pogubić się w obliczeniach. Potrzebuje też więcej czasu na przeczytanie zapisu matematycznego, chemicznego czy fizycznego.

Największa różnica w uzyskanej średniej ocen między grupami dotyczy informatyki i jest to 1,587 na korzyść widzących (uczniowie słabowidzący uzyskali średnik wynik $=3,464$; widzący $M=5,233$ ). Informatyka jest przedmiotem, na którym uczniowie uczą się wyszukiwania, gromadzenia i przetwarzania informacji pochodzących z różnych źródeł, opracowywania rysunków, tekstów, danych liczbowych, motywów, animacji, prezentacji multimedialnych, rozwiązywania problemów algorytmicznych. Uczeń poznaje także różne języki programowania, czyli tzw. kody. Wystarczy, że opuści jeden znak $\mathrm{w}$ danym kodzie znaków, a cała procedura będzie do napisania od nowa. Dla ucznia z niepełnosprawnością wzroku jest to nie tylko trudne, ale też bardzo wyczerpujące pod kątem pracy wzrokowej nad danym materiałem.

Obliczenia statystyczne dotyczące średnich wyników z poszczególnych przedmiotów uzyskiwanych przez uczniów słabowidzących i widzących w okresie adolescencji wskazują, że istnieją istotne statystycznie różnice $\mathrm{w}$ zakresie takich przedmiotów jak: geografia $(\mathrm{t}$ $=-2,875(58), \mathrm{p}<0,006)$; chemia $(\mathrm{t}=-3,718(58) ; \mathrm{p}<0,001)$, fizyka $(\mathrm{t}=-$ $3,070(58), \mathrm{p}<0,003) ;$ matematyka $(\mathrm{t}=-2,066(58) ; \mathrm{p}<0,043)$, informatyka $(\mathrm{t}=-8,681(58) ; \mathrm{p}<0,000)$. Natomiast wyniki w zakresie średniej $\mathrm{z}$ przedmiotu historia znajdują się na granicy istotności statycznej $(\mathrm{t}=$ $1,943(58) ; \mathrm{p}<0,057)$. Więcej informacji na powyższy temat dostarcza analiza otrzymanego materiału dokonana $\mathrm{w}$ oparciu o wartości średnich arytmetycznych. Uczniowie słabowidzący we wszystkich 
wymienionych przedmiotach uzyskują niższe rezultaty. Może to być spowodowane tym, że podczas wyżej wspomnianych zajęć wymagana jest głównie praca wzrokowa np. przy zapisie równań chemicznych, podstawianiu i zamienianiu symboli w równaniach, wykreślaniu różnych funkcji, wykreślaniu wektorów, co jest możliwe przy dobrej organizacji przestrzennej na kartce. Dziwić może sytuacja, że z przedmiotu takiego jak geografia uczniowie słabowidzący uzyskują wyniki niższe aż o 0,67 oceny. Wprawdzie na lekcjach geografii nie trzeba wykreślać wzorów, ale jest to praca z mapą. Tak jak w fizyce wskazana jest dobra orientacja przestrzenna w celu lokalizacji danego miejsca, co oznacza, że nie każdy słabowidzący potrafi sobie $\mathrm{z}$ tym zadaniem poradzić.

Dokonując analizy średnich wyników, można zauważyć, iż w zakresie przedmiotu zajęcia techniczne grupa uczniów słabowidzących i widzących różni się istotnie $(\mathrm{t}=-1,238(58) ; \mathrm{p}<0,022)$. W grupie uczniów słabowidzących odnotowano istotnie niższy średni wynik $(M=4,613)$ niż w grupie uczniów widzących $(\mathrm{M}=4,866)$. $\mathrm{Z}$ podstawy programy podstawowej wynika, że jest to przedmiot, na którym uczniowie rozpoznają i rozumieją potrzebę budowania różnych typów modeli, opracowują rozwiązania dla typowych problemów technicznych pojawiających w projektowaniu (rysują schematy blokowe, porównują funkcje budowanych modeli, przedstawiają szkice), opracowują szczegółowe rozwiązania konstrukcyjne, projektują np. prace modelarskie o różnym stopniu złożoności, uczą się posługiwać narzędziami i przyrządami modelarskimi oraz uruchamiają zbudowane przez siebie modele, jeżeli są takie budowane. Zajęcia techniczne mogą być realizowane $\mathrm{w}$ postaci zajęć krawieckich, elektronicznych, zajęć z rękodzieła. Należy zwrócić uwagę, że niezależnie od tego, w jakiej formie realizowane będą zajęcia techniczne, wszystkie wymagają od ucznia wykorzystywania funkcji wzrokowych. W przypadku uczniów słabowidzących możliwości te są ograniczone, tempo pracy często obniżone ze względu na czas potrzebny na zapoznanie się wzrokowe $\mathrm{z}$ drobnymi elementami. Zajęcia techniczne wymagają bardzo dużej precyzji i skrupulatności, odmierzania, wyliczania i sprawdzania czy każdy element np. 
budowanego modelu do siebie pasuje. Uczeń słabowidzący nie zawsze ma możliwość, nawet podczas wspomagania się najnowszymi urządzeniami optycznymi i nieoptycznymi, określić, dlaczego jego model nie działa, w którym miejscu źle połączył elementy ze sobą, dlaczego drobne elementy do siebie nie pasują.

Biorąc pod uwagę wartość „,t" Studenta zauważa się, iż w zakresie przedmiotu zajęcia artystyczne między grupą uczniów słabowidzących a uczniami widzącymi istnieje różnica istotna statystycznie $(\mathrm{t}=5,130(58), \mathrm{p}<0,000)$. Młodzież słabowidząca $\mathrm{w}$ porównaniu do uczniów widzących uzyskała wyższe średnie wyniki z tego przedmiotu. W podstawie programowej zwrócono uwagę, że zajęcia te powinny być związane z jedną dyscypliną sztuki lub mieć charakter interdyscyplinarny, mogą to być zajęcia plastyczne, muzyczne, czy koło teatralne. Zajęcia artystyczne prowadzone mogą być w postaci albo projektu, albo regularnych lekcji, w zależności od możliwości i zasobów szkoły, a także zainteresowań uczniów. Ponieważ badania zostały przeprowadzone w ośrodku szkolno-wychowawczym i w ogólnodostępnym gimnazjum, uczniowie słabowidzący i widzący mogli uczęszczać na zajęcia o innym profilu, stąd rozbieżność średnich wyników na korzyść słabowidzących. Należy też pamiętać, że grupa słabowidzących jest bardzo zróżnicowana - ostrość wzroku słabowidzących może być - od 0,03 do 0,05. Powoduje to, że niektórzy uczniowie potrzebują tylko np. powiększonego obrazu, a inni nie mogą pracować wzrokowo dłużej niż 30 minut i wymagają przerwy od bodźców wzrokowych. Jeżeli uczniowie słabowidzący na zajęciach artystycznych rozwijali swoje umiejętności plastyczne i wykonywali prace, które nie wymagały zaangażowania wzroku (stosowane techniki bezwzrokowe), a opierali się na pozostałych zmysłach, mogli otrzymać wyższe oceny z tego przedmiotu niż uczniowie widzący. Widzący ponad $80 \%$ informacji czerpią $\mathrm{z}$ danych pochodzenia wzrokowego. Jeżeli mają wykonać pracę np. w glinie, może się okazać, że jest to dla nich zadanie bardzo trudne, a brak poczucia bezpieczeństwa wzrokowego może hamować rozwój ekspresji. W przypadku, gdy zajęcia artystyczne mają charakter zajęć muzycznych, uczniowie słabowidzący mogą wykorzystywać 
swoją dobrą pamięć słuchową, co również może się przyczyniać do osiągania wyższych rezultatów od widzących.

Istnieje również różnica istotna statystycznie między obiema grupami w zakresie zachowania $(\mathrm{t}=-3,342(58), \mathrm{p}<0,001)$ na korzyść uczniów widzących. Oznaczać to może, że uczniowie słabowidzący nie zawsze zachowują się zgodnie z normami przyjętymi w danej szkole, co powoduje obniżenie oceny ze sprawowania. Ich społecznie nieakceptowane zachowania nie muszą wcale wynikać z nieznajomości zasad społecznych, ale z braku wyobrażenia sobie, co się stanie, gdy postąpią tak a nie inaczej oraz z braku umiejętności przewidywania. Innym wyjaśnieniem może być fakt, że uczniowie słabowidzący mają mniejsze możliwości obserwacji różnych zachowań z powodu zawężonego pola widzenia.

Uzupełnieniem rozważań na temat związków między samoświadomością emocji a osiągnięciami szkolnymi uczniów słabowidzących i widzących jest określenie istotnych statystycznie zależności, jakie występują między poszczególnymi zmiennymi.

W grupie uczniów z niepełnosprawnością wzroku występują cztery istotne zależności. Istnieje ujemna, umiarkowana, istotna statystycznie zależność między poziomem Ujawniania Emocji a wynikami $\mathrm{z}$ takiego przedmiotu jak chemia $(\mathrm{r}=-0,528$; $\mathrm{p}<0,003)$ oraz ujemna, niska, istotna statystycznie zależność między poziomem Ujawniania Emocji a wynikami z takiego przedmiotu jak informatyka $(\mathrm{r}=-0,365 ; \mathrm{p}<0,048)$. Takie zależności mogą świadczyć o tym, że im uczniowie osiągają wyższe oceny z tych dwóch ścisłych przedmiotów, tym najprawdopodobniej mają większe poczucie lęku przed ujawnieniem swoich emocji. Nie chcą pokazywać swoich emocji, gdyż obawiają się reakcji nauczyciela. Natomiast między poziomem Świadomości Reakcji Fizjologicznych Organizmu a takimi przedmiotami jak informatyka $(\mathrm{r}=-0,365 ; \mathrm{p}<0,48)$ i zajęcia artystyczne $(\mathrm{r}=-0,365 ; \mathrm{p}<0,48)$ istnieją zależności ujemne, niskie, istotne statystycznie. Oznacza to, że im wyższe oceny uczniowie słabowidzący osiągają z powyższych dwóch przedmiotów, tym mniej analizują zachowania swojego organizmu, gdyż koncentrują się na sukcesie, czyli wysokiej ocenie i nie skupiają się na tym, jak reaguje ich organizm. 
W grupie uczniów widzących w okresie adolescencji istnieje ujemna, niska, istotna statystycznie zależność między poziomem Ujawniania Emocji a osiąganymi wynikami z takich przedmiotów jak: jezzyk polski $(\mathrm{r}=-0,384 ; \mathrm{p}<0,040)$ oraz jezzyk obcy $(\mathrm{r}=-0,366$; $\mathrm{p}<0,046)$ oraz istnieje ujemna, umiarkowana, istotna statystycznie zależność między poziomem Świadomościa Reakcji Fizjologicznych Wtasnego Organizmu a wynikiem otrzymywanym biologii $(\mathrm{r}=-0,413$; $\mathrm{p}<0,023)$.

\section{Podsumowanie i wnioski}

Celem zaprezentowanych badań było określenie, czy i jakie różnice istnieją $\mathrm{w}$ zakresie osiągnięć szkolnych uczniów $\mathrm{z}$ niepełnosprawnością wzroku i uczniów widzących w okresie adolescencji oraz czy i jakie zależności istnieją pomiędzy samoświadomością stanów emocjonalnych pojawiających się u uczniów z niepełnosprawnością wzroku znajdujących się w okresie adolescencji, a ich osiągnięciami w nauce szkolnej.

Analizowane wyniki wskazują, że między uczniami z niepełnosprawnością wzroku i widzącymi rówieśnikami w okresie adolescencji istnieją różnice istotne statystycznie $\mathrm{w}$ zakresie następujących przedmiotów: historia, geografia, chemia, matematyka. fizyka, informatyka, zajęcia artystyczne i techniczne oraz zachowanie. Oprócz zajęć artystycznych w każdym przedmiocie uczniowie słabowidzący osiągają niższe wyniki. Przyczyny należy szukać $w$ tym, że muszą się oni często wspomagać różnymi pomocami dydaktycznymi, aby zrozumieć poszczególne treści. Poza tym posługiwanie się mapă, np. podczas lekcji historii czy geografii, kiedy nie można spojrzeć na daną planszę globalnie, tylko trzeba dzielić informacje na części, może utrudniać kodowanie danych. Chemia, fizyka, matematyka to przedmioty ścisłe, które od ucznia wymagają zapisu ciągów cyfr, zamian znaków i również całościowego spojrzenia na rząd liczb i symboli, wektorów i schematów. Uczeń z organicznymi możliwościami per- 
cepcyjnymi może skupiać się głównie na próbie odczytania z użyciem pomocy optycznych i nieoptycznych danego ciągu, a nie na rozwiązaniu.

Analizowane wyniki wskazują, że w przypadku badanej grupy uczniów słabowidzących w okresie adolescencji między poziomem Ujawnianych Emocji i poziomem i Świadomością Reakcji Fizjologicznych Organizmu a osiąganymi wynikami w nauce $\mathrm{z}$ takich przedmiotów jak chemia, informatyka i zajęcia artystyczne istnieją zależności istotne statystycznie. Im wyższe uczniowie osiągają rezultaty z tych przedmiotów, tym większa może pojawiać się obawa przez ujawnianiem emocji.

W związku z powyższym bardzo ważne jest, aby wspomóc uczniów przez przygotowanie odpowiednich programów profilaktycznych, zajęć, warsztatów dotyczących poznawania doświadczanych emocji. Wskazane byłoby też organizowanie treningu mającego pokazać, jak reaguje ciało w rożnych sytuacjach - zarówno tych przyjemnych, jak i tych trudnych, stresogennych. Uczniowie, wykonując różne eksperymenty chemiczne czy osiągając sukces informatyczny, mają większą potrzebę ujawniania swoich emocji i stają się w tym zakresie bardziej świadomi. Podobna sytuacja może również dotyczyć zajęć artystycznych. Dlatego też należy zapewnić uczniom słabowidzącym możliwość ekspresji i prób rozumienia tego, co odczuwają

Poznanie, rozumienie i umiejętność analizowania przeżywanych emocji jest bardzo ważna w procesie kształtowania się relacji z innymi ludźmi, tworzenia związków, nabywania kompetencji przydatnych w dorosłym życiu. Samoświadomość własnych stanów emocjonalnych pozwala na samorozwój, zwiększa poczucie własnej skuteczności oraz samoocenę. Dlatego też placówki edukacyjne i rehabilitacyjne, w których uczą się uczniowie w okresie adolescencji, powinny nie tylko przekazywać wiedzę dotyczącą podstawy programowej, ale także zwracać uwagę na pojawiające się emocje i dać możliwość uzewnętrznienia ich celem próby zrozumienia. 


\section{Bibliografia}

Arshad M., Lodhi M., Congenital Blind and Sight; Emiotional Inteligence Sighted, "The Proffesional Medical Journal" 2015, 22(10).

Beaty L.A., Adolescent self-perception as a function of vision loss, "Adolescence" 1992, 27.

Bar-On R., Emotional Quotient Inventory. A measure of emotional intelligence. User's manual, Multi-Health Systems Inc., Toronto 1997.

Feldmann M., Jeffery P., Co-curricular Assessment Scale Development, "The Journal of General Education" 2011, 60, 1.

Gardner H., Inteligencje wielorakie. Teoria w praktyce, Media Rodzina, Poznań 2002.

Goleman D. Inteligencja emocjonalna. Sukces w życiu zależy nie tylko od intelektu lecz od umiejętności kierowania emocjami, Media Rodzina, Poznań 2012.

Goleman D., Inteligencja emocjonalna w praktyce, Media Rodzina, Poznań 1999.

Izard C.E., Emotional intelligence or adaptive emotions?, "Emotion” 2001, 1.

Jaworowska A., Matczak A., Kwestionariusz Inteligencji Emocjonalnej INTE S. Schutte, J. M. Malouffa, L. E. Hall, D. J. Haggerty'ego, J. T. Cooper, C. J. Goldena, L. Dornheim. Podręcznik, Pracownia Testów Psychologicznych PTP, Warszawa 2008.

Kumar S., Singh J., Emotional intelligence and adjustment among visually impairment and sighted school students, "Asian Journal of Multi-Dimensional Research" 2013, 2(8).

Ledzińska M., Elementy poznawcze $i$ metapoznawcze w inteligencji - od inteligencji poznawczej do emocjonalnej, „Psychologia Wychowawcza”, 1999, 42.

Matczak A., Zarys psychologii rozwoju. Podręcznik dla nauczycieli, Wydawnictwo Akademickie „Żak”, Warszawa 2003.

Matczak A., Knopp K.A., Znaczenie inteligencji emocjonalnej w funkcjonowaniu człowieka, Wydawnictwo Stowarzyszenie Filomatów, Liberi Libri 2013.

Mayer J.D., Salovey P., Czym jest inteligencja emocjonalna?, [w:] Rozwój emocjonalny a inteligencja emocjonalna, red. P. Salovey, D. Sluyter, Dom Wydawniczy Rebis, Poznań 1999.

Obuchowska I. Adolescencja, [w:] Psychologia rozwoju człowieka. Charakterystyka okresów życia, red. B. Harwas-Napierała, J. Trempała, Wydawnictwo PWN, Warszawa 2000, t. 2.

Parween S., Variables Influencing Emotional Intelligence of Visually Impaired Students in Higher Education. "Disability, CBR and Inclusive Development DCID", 2015, vol. 26(1).

Radochoński M., Psychopatologia życia emocjonalnego dzieci i młodzieży. Wybrane zagadnienia, Wydawnictwo Uniwersytetu Rzeszowskiego, Rzeszów 2009.

Rani R., Emotional intelligence and academic achievement of visually disabled students in integrated and segregated schools, "Disabilities and Impairments" 2011, 25(1\&2). 
Rieffe C., Oosterveld P., Miers A.C., Terwogt M.M., Ly V., Emotion Awareness and Internalizing Symptoms in Children and Adolescents; The Emotion Awareness Questionnaire Revised, „Personality and Individual Differences” 2008, 45.

Rietti S., Emotional Intelligence as Educational Goal: A Case for Caution, "Journal of Philosophy of Education" 2008, 42(3-4).

Salovey P., Mayer J.D., Emotional intelligence, "Imagination, Cognition, and Personality" 1990, 9.

Saarni C., Kompetencja emocjonalna i samoregulacja w dzieciństwie, [w:] Rozwój emocjonalny a inteligencja emocjonalna, red. P. Salovey, D.J. Slyter, Dom Wydawniczy Rebis, Poznań 1999.

Thompson R.A., Emotion regulation: a theme in search of definition, "Monographs of the Society for Reaserch in Child Development" 1994, nr 2-3.

Wytykowska A., Petrides K.V., Inteligencja emocjonalna jako dyspozycja. Polska adaptacja skali do badania inteligencji emocjonalnej jako cechy TEIque Petridesa i Furnhama, „Psychologia, Edukacja i Społeczeństwo” 2007, 4. 